\title{
KULT CESARSKI NA OBSZARZE PROWINCJI HISZPAŃSKICH - REZULTAT POLITYKI IMPERIALNEJ RZYMU, CZY ODDOLNEJ INICJATYWY MIESZKAŃCÓW?
}

\author{
Damian Side1 ${ }^{1}$ \\ https://doi.org/10.18778/8220-421-6.14
}

\begin{abstract}
This chapter discusses the issue of the imperial cult on the Iberian Peninsula at the beginnig of the principate. In the first part of the chapter, the stages of development of the imperial cult in the Iberian Peninsula are briefly described. Its main centre was located in Tarraco, the capital city of Hither Spain. Two other provinces - Baetica and Lusitania followed in its footsteps. In the second part, epigraphic and numismatic evidence showing the Iberians' attitude towards emperor worship are analysed. The author tries to prove that the creation of emperor rituals in the whole Peninsula was dominated by the initiative of the Iberians themsleves.
\end{abstract}

Keywords: Imperial Cult, Iberian Peninsula, Roman religion, JulioClaudian dynasty, the Flavians.

Słowa kluczowe: kult cesarski, Półwysep Iberyjski, religia rzymska, dynastia julijsko-klaudyjska, Flawiusze.

1 Doktorant w Zakładzie Historii Starożytnej Uniwersytetu Jagiellońskiego, ul. Gołębia 13, Kraków 31-007, damian.sidel@doctoral. uj.edu.pl. 


\section{Wstęp}

Przedmiotem badań przedstawionych w niniejszym rozdziale jest kult cesarski na obszarze trzech prowincji hiszpańskich w okresie pryncypatu. Okoliczności wprowadzenia takiego kultu na Półwyspie Iberyjskim, jego formy oraz postawa jaką wobec niego zajęli mieszkańcy, mogą stanowić ważne źródło informacji, mówiące o relacjach łączących prowincje hiszpańskie ze stolicą Imperium, a także pokazujące stosunek mieszkańców do cesarza i rodziny cesarskiej. Głównym celem rozdziału będzie próba określenia charakteru postawy mieszkańców Półwyspu Iberyjskiego wobec form kultu cesarskiego w Rzymie. Zostanie podjęta próba odpowiedzi na pytanie, czy działania Hispanorzymian ${ }^{2}$ w zakresie kreowania form kultu cesarskiego były przejawem ich własnej inicjatywy, czy też były inspirowane przez władze centralne.

Analizie zostaną poddane przede wszystkim przykłady form kultu z I i II wieku naszej ery, ze względu na fakt, że jest to okres najlepiej opisany przez źródła narracyjne. Historia rzymskiej obecności na Półwyspie miała jednak swój początek wcześniej - już pod koniec III w. p.n.e. Rzymianie rozpoczęli jego podbój. W roku 198 p.n.e. dokonano podziału zajętego obszaru na dwie prowincje - Hiszpanię Dalszą (Hispania Ulterior) oraz Hiszpanię Bliższą (Hispania Citerior). Podział ten został zmodyfikowany w okresie panowania Augusta. Historycy datują to wydarzenie na okres między 27 a 14 rokiem p.n.e. Od tego momentu opanowany przez Rzymian obszar Półwyspu składał się z trzech prowincji. Hiszpania Dalsza została podzielona na dwie nowe prowincje - Hiszpanię Dalszą Betykę (Hispania Ulterior - Baetica) oraz Hiszpanię Dalszą Luzytanię (Hispania Ulterior - Lusitania). Stolicami tych prowincji były odpowiednio miasta Corduba i Augusta Emerita. Obszar Hiszpani Bliższej

2 Termin ten zostanie użyty w niniejszym artykule w celu określenia elit zamieszkujących Półwysep Iberyjski i sprawujących funkcje publiczne w tamtejszych miastach. Byli to ludzie o iberyjskim rodowodzie, którzy jednak ulegli już procesowi romanizacji. 
został powiększony. Jej stolicą zostało Tarraco (łac. Hispania Citerior - Tarraconensis). Stolica Hiszpanii Bliższej była najważniejszą spośród wszystkich trzech, stanowiąc centrum administracyjne całego Półwyspu (Machcewicz, Miłkowski, 2009: 22-26).

Rozważania należy zacząć od wyjaśnienia terminu użytego w tytule, bowiem definicja samego kultu cesarskiego wciąż stanowi przedmiot polemik badaczy antyku. Wynikają one w dużej mierze z faktu, iż termin „kult cesarski” został sztucznie wykreowany przez historyków religii rzymskiej w końcu XIX wieku. Sami Rzymianie nie używali żadnego konkretnego terminu na określenie rytuałów mających na celu oddawanie czci cesarzowi ${ }^{3}$. W niniejszym rozdziale termin kult cesarski będzie stosowany według definicji zaproponowanej przez Petera Herza (1988: 118-120). Według niej kult cesarski obejmował fundację ołtarzy oraz innych obiektów kultowych dla cesarza i jego rodziny, a także związane z nimi organizacje kultowe i święta. W tym pojęciu mieściły się według Herza także: wyniesienie władcy w religijnych formach przez przymioty i akty, utożsamianie władcy z bogami, a także uczynienie władcy punktem odniesienia rytuałów stosowanych wobec innych bogów.

Kult cesarski od momentu uformowania w okresie panowania Augusta stał się nieodłącznym elementem funkcjonowania Imperium Rzymskiego. Jeszcze za panowania tego władcy rozpoczęto próby przeniesienia form kultu cesarskiego na szczebel prowincji.

3 Jako pierwszy zasadność użycia terminu kult cesarski zakwestionował w roku 1973 Elias Bickerman. Według jego argumentacji w starożytnym Rzymie nie istniał żaden uniwersalny model kultu cesarza. Każda prowincja, miasto czy grupa obywateli miała swój sposób na oddawanie mu czci (Bickerman, 1973: 9). Użycie terminu zostało również zakwestionowane w zbiorowej pracy dotyczącej historii religii rzymskiej autorstwa Mary Beard, Jamesa Northa i Simona Price'a, wydanej pod tytułem: Religie Rzymu: historia. Autorzy podobnie jak Bickerman argumentują swoje negatywne stanowisko różnorodnością sposobów oddawania czci cesarzowi, w zależności od miejsca sprawowania rytuałów. Zamiast terminu kult cesarski zaproponowali termin „rytuały cesarskie” (Beard, North, Price, 2017: 201-202). Por. Olszewski, 2010: 356-373. 
Prowincje hiszpańskie były jednymi z pierwszych, które zostały poddane tej praktyce. W związku z tym warto prześledzić rozwój obiektów kultowych na obszarze tych właśnie prowincji, a także przyjrzeć się inskrypcjom dedykacyjnym i monetom bitym w lokalnych mennicach. Baza źródeł historycznych zawierających informacje na temat form kultu cesarskiego na Półwyspie Iberyjskim jest dość obfita. Istnieją wzmianki w źródłach literackich, takich jak Roczniki Tacyta oraz Scriptores Historiae Augustae, które dostarczają nam informacji na temat relacji Rzym - Półwysep Iberyjski w kwestii kształtowania form kultu cesarskiego. Istnieje również liczny materiał epigraficzny i numizmatyczny, który umożliwia podjęcie próby odtworzenia postawy mieszkańców Półwyspu wobec kultu rodziny cesarskiej.

W pierwszej części rozdziału zostaną opisane najważniejsze ośrodki kultu cesarskiego, funkcjonujące na obszarze Półwyspu Iberyjskiego wraz z istniejącymi tam miejscami kultu takimi jak ołtarze czy świątynie. W kolejnych częściach zostaną przedstawione funkcjonujące tam najważniejsze instytucje i kolegia kapłańskie związane z kultem cesarskim. Na końcu zostanie dokonana analiza źródeł epigraficznych i numizmatycznych, które obrazują postawę Hispanorzymian wobec form kultu cesarskiego. Zostanie również dokonane krótkie porównanie z sytuacją zaobserwowaną w pozostałych prowincjach zachodniej części Imperium Rzymskiego.

\section{2.}

\section{Ośrodki kultu cesarskiego na Półwyspie}

Najstarszym obiektem na Półwyspie, wystawionym w celu oddania czci cesarzowi mógł być ołtarz dedykowany mu w Tarraco. Kwintylian, poeta tworzący w drugiej połowie I w. n.e., w swoim dziele pt. Kształcenie mówcy wspomina o ołtarzu dedykowanym Augustowi w Hiszpanii Tarrakońskiej. Według tego przekazu na ołtarzu miała wyrosnąć palma, o czym cesarza poinformowali posłowie z Tarraco (Quint. Inst. 6.3.77). U Rzymian palma symbolizowała boską naturę. Wyrośnięcie 
palmy w niespodziewanym miejscu uznawano za prodigium zapowiadające zwycięstwo ${ }^{4}$. Ołtarz wraz z wyrastającą z niego palmą pojawił się również na rewersie monety wyemitowanej w Tarraco, w ramach serii z legendami Deo Augusto i Divus Augustus Pater, datowanej na okres po roku 15 n.e. (RPC 218, 221). Przedstawione powyżej źródła niestety nie pozwalają nam na precyzyjne wydatowanie momentu powstania ołtarza. Na pewno powstał on przed wybiciem monet $\mathrm{w} 15$ roku n.e. Przekazana przez Kwintyliana informacja o poselstwie potwierdza, że ołtarz powstał jeszcze za panowania Augusta. Można jedynie przypuszczać, że ów ołtarz został dedykowany w czasie, gdy August przebywał w Hiszpanii i wizytował Tarraco. Takie wydarzenie miało miejsce w latach $26-25$ p.n.e., w trakcie tłumienia powstania Kantabrów i Asturów (Cass. Dio LIII, 25-26) ${ }^{5}$. Nie jest również pewne jakiej formie kultu Augusta dedykowano ołtarz. Najprawdopodobniej był on poświęcony kultowi Augusta połączonemu z kultem bogini Romy. Przemawia za tym informacja podana przez Swetoniusza i Kasjusza Diona, dotycząca decyzji Augusta o ustanowieniu kultu jego osoby połączonego z kultem bogini Romy w azjatyckich miastach - Pergamonie i Nikomedii. Była to odpowiedź na poselstwo przysłane przez mieszkańców tych miast. Zabieg połączenia kultu cesarza $\mathrm{z}$ boginią Romą miał na celu uniknięcie oskarżenia o wywyższenie swojej osoby do grona bóstw (Suet. Aug. 52; Cass. Dio LI 20, 6-7; Fishwick, 1978:

4 Jako prodigium zapowiadające zwycięstwo zdarzenie wyrośnięcia palmy pojawiło się między innymi w dziele Juliusza Cezara pt. O wojnie domowej, gdzie według przekazu miała wyrosnąć spomiędzy kamieni tworzących posadzkę pomieszczenia, w którym Cezar ufundował posąg Wiktorii (Caes. BCiv. 3.105.6). W takim samym kontekście palma pojawiła się w Historii Naturalnej Pliniusza Starszego, gdzie została opisana jako zapowiedź zwycięstwa nad Pyrrusem. Według tego przekazu miała wyrosnąć na ołtarzu Jowisza znajdującym się na Kapitolu (Plin. HN 17.244). Fishwick zasugerował, iż palma dostrzeżona w Tarraco mogła być kojarzona z zapowiedzią zwycięstwa nad Kantabrami i Asturami (Fishwick, 1987: 175) Por.: Kopaliński, 1990: 297-300 (palma).

5 Por. Sutherland, 1934: 32; Fishwick, 1999: 129. 
1206-1207). Za taką dedykacją może również przemawiać inskrypcja znaleziona w Tarraco, wymieniająca kapłana Romy i Augusta (CIL II 6097). Niestety nie zawiera ona elementów pozwalających na jej wydatowanie. Robert Étienne (1958: 206) uznał, iż datowanie tej inskrypcji na okres panowania Augusta jest możliwe. Duncan Fishwick (1987: 177) wysunął natomiast przypuszczenie, że mogła ona powstać już po śmierci Augusta. Dość istotną kwestią jest także status ołtarza. Zarówno Étienne jak również Fishwick przyjęli, że ołtarz miał status municypalny. Étienne zasugerował, że kult prowincjonalny został zapoczątkowany wraz z wystawieniem świątyni. Według niego została ona wybudowana obok funkcjonującego już ołtarza na akropolu miasta. Fishwick nie zgodził się z takim umiejscowieniem obiektu. Bazując na nowych odkryciach archeologicznych opowiedział się za umiejscowieniem ołtarza w pobliżu forum kolonialnego. W jego opinii ołtarz był niezależny od powstałej później w zupełnie innym miejscu świątyni prowincjonalnej, w związku z tym musiał mieć inny, municypalny status. (Étienne, 1958: 369-371; Fishwick, 2014: 351-355).

Kolejnym etapem rozwoju kultu cesarskiego w Tarraco było wystawienie świątyni dedykowanej boskiemu Augustowi (Divus Augustus). W tym przypadku również istnieje problem $\mathrm{z}$ ustaleniem dokładnej daty jej powstania. Z przekazu Tacyta dowiadujemy się o poselstwie jakie mieszkańcy tej prowincji przysłali do cesarza Tyberiusza w roku 15 n.e. Posłowie przybyli zapytać cesarza o zgodę na wybudowanie świątyni dla boskiego Augusta. Tyberiusz przychylił się do ich prośby. Tacyt komentuje to wydarzenie stwierdzeniem, że w ten sposób dano przykład innym prowincjom („Templum ut in colonia Tarraconensi strueretur Augusto petentibus Hispanis permissum, datumque in omnis provincias exemplum" Tac. Ann. I 78). W nauce wciąż trwa spór o interpretację owego fragmentu. Zdaniem części badaczy chodzi o prowincje cesarstwa w znaczeniu ogólnym. Hiszpania Tarrakońska miałaby stworzyć precedens, według którego postępowały kolejne prowincje cesarstwa, które chciały dedykować świątynię boskiemu Augustowi. Pozostała część badaczy opowiada się za interpretacją zakładającą, iż wspomniany passus 
dotyczy przykładu jaki Tarraco dało pozostałym prowincjom z Półwyspu Iberyjskiego (Fiske, 1900: 134-136; Étienne, 1958: 409-410; Fishwick, 1999: 121-122). Za taką interpretacją może przemawiać fakt, że w innym fragmencie Roczników, pod rokiem 25 n.e. opisane zostało poselstwo mieszkańców Betyki do Tyberiusza, którzy również prosili o zgodę na budowę świątyni, tym razem dedykowanej Tyberiuszowi i Liwii (Tac. Ann. IV 37). Niemniej w innym miejscu Roczniki informują nas o poselstwach od mieszkańców prowincji z innych części Imperium, wysyłanych z tym samym zapytaniem, jak na przykład poselstwo od mieszkańców prowincji Azja (Tac. Ann. IV 15, 55). To może sugerować, że przykład dany przez Tarrakończyków mógł dotyczyć nie tylko Półwyspu Iberyjskiego.

Innym źródłem wskazującym na istnienie świątyni w Tarraco jest wspomniana wyżej emisja monet datowana na lata 15-22 lub 22-23 n.e (RPC 218, 222, 224, 226). Rewers niektórych monet z serii opatrzonych legendami Deo Augusto i Divus Augustus Pater zawierał przedstawienie ośmiokolumnowej świątyni. Wizerunek świątyni w połączeniu z legendą wskazującą boskiego Augusta pozwala wysunąć przypuszczenie, że rewers wspomnianych monet przedstawia wizerunek prowincjonalnej świątyni dedykowanej temu cesarzowi. Może za tym przemawiać również fakt, że większość znanych nam świątyń prowincjonalnych została oparta na ośmiu kolumnach. Wydaje się jednak mało realne, że świątynia powstała po upływie tak krótkiego czasu od momentu przysłania poselstwa. Bardziej prawdopodobne jest to, że rewers zawiera wizerunek projektu świątyni (Por. Fishwick, 1999: 125-126).

Niestety nie posiadamy dokładnej informacji na temat tego, kiedy nastąpiło zakończenie budowy i dedykacja świątyni prowincjonalnej w Tarraco. Kolejne dwie wzmianki na temat tej budowli znajdujemy w zbiorze Scriptores Historiae Augustae. Dotyczą one jednak już kwestii jej odbudowy. Z pierwszego fragmentu wynika, że Hadrian, odbywając swoją podróż po zachodnich prowincjach Imperium odwiedził Tarraco. Miało to miejsce w roku 121 lub 122. Cesarz najprawdopodobniej zatrzymał się w Hiszpanii, będąc w podróży, której celem była 
Brytania. Wówczas Hadrian spotkał się z mieszkańcami prowincji, obiecując im odbudowę przybytku (H. A. Hadr. 12.4). Inny fragment dotyczy roku 177. Wówczas Hiszpanię Tarrakońską odwiedził Septymiusz Sewer, wysłany tam jako namiestnik. On również zauważył konieczność odbudowy świątyni (H. A. Sept. Sever 3.4). Niestety nie można określić czym była spowodowana ta konieczność. Być może Hadrian nie spełnił swojej obietnicy lub też świątynia uległa ponownemu zniszczeniu.

W sytuacji braku wystarczających informacji pochodzących ze źródeł pisanych, warto zwrócić uwagę na dane jakich dostarczyły prace archeologiczne przeprowadzone na obszarze ruin świątyni. Wykopaliska w Tarraco przeprowadzono trzykrotnie: w latach 1955, 1984 i 1986. Dwie ostatnie misje badawcze zostały przeprowadzone przez archeologów z Taller Escola d’Arqueologia de Tarragona. Dzięki nim udało się odkryć pozostałości świątyni ulokowanej na tarasowanym, trzystopniowym wzgórzu. Świątynia tworzyła kompleks wraz z cyrkiem i rozległym placem służącym do organizowania spotkań. Praca archeologów przyniosła też drobne odkrycia, które mogą pomóc w datowaniu etapów powstawania świątyni. Na najniższym tarasie natrafiono na monetę, którą udało się wydatować na rok 42 n.e. Prace wykopaliskowe przeprowadzone na obszarze średniego tarasu pozwoliły odkryć materiał epigraficzny datowany na lata 69-70 n.e. Wykopaliska zrealizowane na najwyższym tarasie zaowocowały natomiast odkryciem pozostałości ceramicznych również datowanych na ten sam okres (Fishwick, 1999: 125-129; 2004: 11-22; Keay, 2003: 176-179).

Efekty badań archeologicznych przemawiają za tym, że świątynia powstawała stopniowo. Pierwszy taras mógł zostać ukończony już za panowania Klaudiusza. Kolejne dwa mogły zostać dokończone na polecenie Wespazjana. Sfinalizowanie budowy przez tego właśnie cesarza wydaje się prawdopodobne, gdyż w okresie panowania Flawiuszy nastąpiło ponowne zainteresowanie wspieraniem rozwoju kultu cesarskiego na Półwyspie Iberyjskim. Przemawia za tym fakt, iż to właśnie na okres panowania tej dynastii datowana jest najstarsza inskrypcja potwierdzająca funkcjonowanie kapłana kultu cesarskiego (flamen) w sąsiedniej 
Betyce (CIL II 3271). Wśród badaczy pojawia się sugestia, iż organizacja kultu cesarskiego w Betyce miała miejsce w tym samym okresie, co analogiczne działania w Afryce Prokonsularnej, czyli w przybliżeniu w latach 70-72 n.e. ${ }^{6}$ Być może w tym samym okresie zorganizowano również kult prowincjonalny w Galii Narbońskiej ${ }^{7}$. Jeżeli te przypuszczenia są wiarygodne należy przyjąć, że reorganizacja kultu cesarskiego w tych trzech prowincjach miała miejsce w tym samym okresie i została przeprowadzona właśnie przez Wespazjana.

Taki długi okres budowy świątyni nie jest niczym zaskakującym. W samym Rzymie zdarzało się, że od momentu ogłoszenia decyzji o budowie świątyni do momentu jej dedykacji mijało kilkadziesiąt lat. Przykładem takiej świątyni może być wspomniana wyżej świątynia Marsa Mściciela. Oktawian ogłosił chęć jej wystawienia w roku 42 p.n.e. w ramach polityki propagandowej zakładającej dążenie do pomszczenia zmarłego ojca - Juliusza Cezara. Świątynia została jednak ukończona dopiero w 2 roku p.n.e., kiedy dedykowano ją wraz z forum Augusta (Suet. Aug. 29). Podobnie było z Templum Novum Divi Augusti, świątynią, której zamiar budowy Tyberiusz ogłosił na początku swojego panowania, ale została dedykowana

6 Datowanie początków kultu cesarskiego w Afryce Prokonsularnej na lata 70-72 zostało oparte na treści inskrypcji pochodzącej z tej prowincji, która wymienia P. Mummiusa Saturninusa, kapłana kultu cesarskiego (Sacerdos Provinciae Africae). Inskrypcja datowana jest na lata 183-185 n.e. W jej treści zaznaczono, że Saturninus jest 113 kapłanem. Na podstawie tej informacji można założyć, że pierwszy kapłan objął swój urząd w Afryce Prokonsularnej w latach 70-72 n.e. Zob. CIL VIII 12039; Fishwick, 1987: 257-260.

7 Przemawia za tym tak zwane Lex Narbonensis, prawo to zachowało się w formie inskrypcji znalezionej w Narbo. Tekst inskrypcji opisuję zasady na jakich ma funkcjonować zorganizowany w tym mieście kult prowincjonalny. Określa powołanie kapłana kultu - flamena i rady prowincjonalnej - concillium. Niestety znaczny stopień uszkodzenia inskrypcji nie pozwala na jej precyzyjne wydatowanie. Jedynie fragment anno fla[...] pozwala przypuszczać że prawo zostało ustanowione w okresie panowania Flawiuszy. Por. Fishwick, 1978: 1222-1223. 
dopiero przez jego następcę, Kaligulę (Cass. Dio LIX 7; Tac. Ann. VI 45). W przypadku świątyni w Tarraco na długi czas budowy mogła mieć wpływ konieczność sprowadzenia odpowiednich fachowców i materiałów niezbędnych do budowy. Istotne znaczenie musiała mieć także konieczność zebrania odpowiednich środków pieniężnych. Budowa świątyni musiała być bardzo kapitałochłonna, a pokryciem kosztów zostali obarczeni najprawdopodobniej mieszkańcy kolonii. Może za tym przemawiać analogia do Camulodunum. W tej brytyjskiej kolonii również wybudowano świątynię o statusie prowincjonalnym. Jej budowa zakończona została najpewniej na krótko przed wybuchem powstania Budyki, ponieważ, według przekazu Tacyta, została ona zniszczona w trakcie toczących się walk. Tacyt podaje również, że jedną z przyczyn wybuchu buntu było obłożenie miejscowej ludności wysokimi daninami, z których zysk przeznaczano na utrzymanie kapłanów i organizowanie przez nich igrzysk (Tac. Ann. XIV 31). Istnieje prawdopodobieństwo, że część pozyskanych w ten sposób pieniędzy przeznaczono na sfinansowanie budowy świątyni. Taką sugestię poparł Fishwick (1972: 164-168).

W sposób analogiczny do Tarraco rozwijano kult cesarski w dwóch pozostałych prowincjach Półwyspu. W kolejnych akapitach zostaną omówione etapy powstawania obiektów kultowych w Luzytanii i Betyce.

W przypadku Emerita Augusta najstarszym śladem kultu cesarskiego jest emisja monet z legendą Divus Augustus Pater. Jest to emisja analogiczna do tej z Tarraco, w związku z czym, podobnie jak ona, jest datowana na początek panowania Tyberiusza. Treść legend awersu i rewersu, a także wizerunek awersu są w obu przypadkach takie same. Różni te monety jedynie wygląd świątyni przedstawionej na rewersie. Tutaj jest to obiekt czterokolumnowy (RPC 47). Podobnie jak w Tarraco, mało prawdopodobne jest, że przedstawiona świątynia była ukończoną budowlą w momencie emisji monety. W tym przypadku również wizerunek najpewniej odzwierciedlał projekt planowanego obiektu (Fishwick, 1999: 131-132; 2004: 41-43). Zastanawiający jest brak informacji o poselstwie wysłanym przez mieszkańców Luzytanii do cesarza, z prośbą o zgodę na budowę świątyni. Wydaje się, że zgodnie z przykładem danym 
przez mieszkańców Tarraco powinni oni wysłać takie poselstwo. Być może miało ono miejsce, lecz informacja o nim nie wzbudziła zainteresowania historyków.

Warto również zwrócić uwagę, że niektóre rewersy monet wyemitowanych w ramach tej samej serii zawierają przedstawienie ołtarza swoim wyglądem przypominające to umieszczone na rewersie monet emitowanych w Tarraco (RPC 35). Na tej podstawie możemy spekulować, iż w Augusta Emerita budowa świątyni również została poprzedzona wystawieniem ołtarza dedykowanego cesarzowi i bogini Romie. Jak dotąd nie udało się jednak odnaleźć innego źródła informującego o istnieniu takiego ołtarza. Fishwick zasugerował, że wizerunek na rewersie mógł powstać jedynie w wyniku naśladowania emisji z Tarraco (Fishwick, 1987: 183).

Niestety żadne z prac archeologicznych, przeprowadzonych dotychczas na obszarze Augusta Emerita, nie przyniosły odkrycia pozostałości obiektu, który mógłby zostać zidentyfikowany jako prowincjonalna świątynia kultu cesarskiego. Pewności co do istnienia świątyni na obszarze tej prowincji dodaje nam fakt, iż w zachowanych inskrypcjach występuje flamen prowincji Luzytanii (CIL II, 41*, CIL II, 473, CIL II, 5264). W samej Augusta Emerita archeologowie odkryli pozostałości dwóch osobnych forów. W obrębie ruin jednego z nich znaleziono obiekty zawierające ikonografię, którą można jednoznacznie identyfikować $\mathrm{z}$ rodziną cesarską. Wśród nich jest blok z inskrypcją podtrzymywaną przez dwie figury będące najprawdopodobniej posągami lub popiersiami Divusa Augusta i Divy Augusty (AE 1997: 777b). Zachowała się również złota protoma, przedstawiająca Tytusa, dedykowana dla niego przez concilium prowincji, któremu przewodzili Marek Juniusz Latro, prowincjonalny kapłan i C. Armitinus Catellus Celler, legat pro pretoria prowincji (CIL II, 5264). Obiekty tego typu zwykle przechowywano w świątyni (Fishwick, 2004: 43-44). Inskrypcja umieszczona na wspomnianej protomie datowana jest na rok 77. Tytus występuje tam jeszcze jako syn cesarza. Treść inskrypcji potwierdza, że w roku 77 w Augusta Emerita istniał już urząd flamena i zbierało się tam concilium. Na tej podstawie możemy przypuścić, że istniała tam również 
już wówczas świątynia prowincjonalna, w której flamen sprawował swoje obrzędy i przewodził obradom concilium. Oprócz tego w ruinach forum znaleziono obiekty wskazujące na to, że mogło ono być wzorowane na forum Augusta, podobnie jak było w przypadku Tarraco i być może również Corduby. Archeolodzy odkopali serię clipei przedstawiające głowę Jupitera Ammona lub meduzy oraz otaczające je kariatydy. Takie clipei otoczone kariatydami znajdowały się na Forum Augusta oraz na forum w Tarraco. W okolicy luzytańskiego forum znaleziono również relief przedstawiający Anchizesa i Eneasza z Augustem oraz przedstawienie postaci w welonie przygotowującej się do złożenia ofiary (Fishwick, 2004: 61-64).

W przypadku Betyki najstarszym przekazem dotyczącym organizacji kultu cesarskiego w prowincji jest wspomniana wyżej relacja Tacyta o poselstwie z roku 25 n. e. (Tac. Ann. IV 37). Według tego przekazu świątynia miała być dedykowana Tyberiuszowi i Liwii. Niestety, wspomniana relacja nie precyzuje pod jaką formą kultową mieli być czczeni cesarz i jego matka. Fakt przysłania poselstwa może sugerować, że planowana świątynia miała mieć status prowincjonalny. W związku z tym można przypuścić, że Tyberiusz i Liwia mieliby tam być czczeni wraz z boskim Augustem, gdyż świątynia prowincjonalna zgodnie z precedensem ustanowionym przez Tarraco powinna być dedykowana boskiemu Augustowi. Z przekazu wynika, że Tyberiusz odmówił wystawienia świątyni. Powodem mogła być właśnie chęć pominięcia boskiego Augusta przy wyborze patronów obiektu. Tacyt przedstawił w swojej relacji mowę jaką Tyberiusz wygłosił przed senatem w celu uzasadnienia swojej decyzji. Wynika z niej, że kierował się przede wszystkim powściągliwością w zakresie odbierania boskiej czci, należnej w jego przekonaniu tylko bóstwom. To może potwierdzać, że planowana świątynia miała być dedykowana przede wszystkim jemu i jego matce, a boski August został pominięty. Étienne wysunął przypuszczenie, że odmowa Tyberiusza zniechęciła mieszkańców Betyki do dalszych starań o uzyskanie zgody na budowę świątyni. Takie wyjaśnienie wydaje się prawdopodobne (Étienne, 1958: 416). 
W okresie panowania Augusta, jak również dynastii julijsko-klaudyjskiej, nie wyemitowano w Betyce żadnej monety, której rewers przedstawiałby świątynie. Jedynym źródłem, które daje pewność istnienia świątyni prowincjonalnej w Cordubie, są inskrypcje wskazujące flamenów Augusti funkcjonujących na obszarze prowincji. Dwie najstarsze pochodzą z końca I w. n.e. Pierwsza z nich, zachowana wyłącznie w postaci nowożytnej kopii, przedstawia fragment cursus honorum nieznanego z imienia rzymskiego urzędnika (CIL II 3271). Z jej treści wynika, że sprawował on funkcję curator Divi Titi, co pozwala datować inskrypcję na okres po roku 81 n.e., w którym miała miejsce deifikacja Tytusa. Treść inskrypcji informuje również o urzędach sprawowanych przez tego urzędnika przed objęciem funkcji kuratora. Wśród nich pojawia się informacja, że był on pierwszym flamenem w Betyce („Flamini Augustali | in Baetica Primo"). Nie ulega wątpliwości, że okres sprawowania tego flaminatu mógł przypaść na okres panowania dynastii Flawiuszy. Funkcja curator Divi Titi wymieniona jest jako pierwsza w cursus honorum, natomiast funkcja flamena jako ostatnia. W tym okresie ów urzędnik sprawował jeszcze urząd prefekta w Galecji i Germanii oraz trybuna legionu ósmego. Tak duża liczba sprawowanych funkcji pozwala przypuszczać, że pomiędzy okresem sprawowania przez niego flaminatu, a okresem sprawowania funkcji kuratora, minęło kilka lat. Zatem pierwszy flaminat w Betyce mógł być sprawowany już w okresie panowania Wespazjana lub wcześniej. Fakt powołania tej osoby na stanowisko curatora Divi Titi, może dowodzić, że sprawowany przez nią flaminat był związany z kultem dynastii Flawiuszy. Wybór kogoś, kto sprawował taki kult na kapłana zajmującego się kultem ubóstwionego członka dynastii wydaje się prawdopodobny. W związku z tym można przypuścić, że flaminat w Betyce został ustanowiony za panowania Wespazjana lub Tytusa.

Druga z zachowanych inskrypcji informuje nas, że w roku 98 n.e. funkcję flamen divorum Augustorum provinciae Baetice sprawował C. Sempronius Speratus. Jest to najstarsze źródło informujące nas o funkcjonowaniu flaminatu w Betyce, które możemy precyzyjnie datować. 
W przypadku Corduby również jak dotąd nie udało się odnaleźć archeologicznych pozostałości świątyni. Wykopaliska prowadzone $\mathrm{w}$ pobliżu młodszego $\mathrm{z}$ forów przyniosły jednak odkrycie fragmentu popiersia $z$ obrazem Eneasza wynoszącego Anchizesa z Troi. Podobny wizerunek znajdował się na Forum Augusta, a także na forum położonym na najwyższym tarasie w Tarraco. To odkrycie może sugerować, iż młodsze spośród dwóch forów odkrytych w Cordubie mogło być wzorowane na Forum Augusta, podobnie jak fora z Tarraco i Emerita Augusta (Fishwick, 2004: 80-82).

\section{3.}

\section{Instytucje związane z kultem cesarskim na Półwyspie Iberyjskim}

Warto podkreślić fakt, iż we wszystkich trzech prowincjach funkcjonował urząd kapłana kultu prowincjonalnego (flamen). Zachowany materiał epigraficzny przedstawia dość zróżnicowaną tytulaturę flamenów: Flamen Augustalis, Flamen Augustalis P.H.C, Flamen Provinciae Baeticae, Flamen Divorum Aug., Flamen Romae et Divorum Augustorum, Flamen Romae divorum et Aug. Fishwick, dokonawszy analizy zachowanego materiału epigraficznego, wysunął hipotezę, że urząd flamena został powołany w celu sprawowania kultu boskiego Augusta. W momencie, gdy następowały deifikacje kolejnych członków rodziny cesarskiej, ich kult włączano do obowiązków flamena. Wiązało się to z koniecznością zmiany tytulatury tego kapłana, co potwierdza inskrypcja z tytulaturą Flamen Divi Augusti et Divae Augustae używaną przez flamena prowincji Luzytanii w roku 48 (AE 1966: 177). Od czasu panowania Wespazjana Flamen Augustorum, oprócz kultu ubóstwionych cesarzy i cesarzowych (divi), sprawował również kult bogini Romy i obecnie panującego cesarza, a jego tytulatura przyjęła formę Flamen Romae et Divorum Augustorum. Włączenie do kultu również żyjących cesarzy było możliwe ze względu na dołączenie do niego kultu bogini Romy (Fishwick, 1970: 311). Innego zdania jest Ėtienne. Według 
jego argumentacji tytuł flamena zmieniał się zależnie od sytuacji. Flamen Augustorum, podobnie jak Flamen Dialis, na którym był wzorowany, był wybierany co roku przez radę prowincji. Takie rozwiązanie umożliwiało aktualizowanie jego tytulatury na bieżąco. W sytuacji, gdy miała miejsce śmierć i deifikacja kolejnego członka rodziny cesarskiej, kult nowego bóstwa mógł być włączony w poczet zadań flamena. Étienne uważa, że kult ubóstwionych cesarzy (divi) był obecny w tych prowincjach, w których jego istnienie potwierdzają zachowane źródła. W podobny sposób kult bogini Romy był sprawowany przez flamena wraz z kultem ubóstwionych cesarzy tylko w tych prowincjach, w których wskazują na to zachowane źródła. W przypadku Betyki brakuje takiego materiału źródłowego, a więc, według Étienne’a, nie było tam takiego kultu (Étienne, 1958: 162-165, 298-299).

Opisana powyżej zmienność tytulatury flamena może potwierdzać ewolucyjny charakter kultu cesarskiego na Półwyspie. Równie prawdopodobne jest jednak to, że jego tytulatura zmieniała się w zależności od sytuacji politycznej. Być może celowo dobierano jego tytulaturę w zależności od tego, czy aktualnie panujący cesarz wolał akcentować kult zmarłych przodków, czy jednak był skłonny zaakceptować kult własnej osoby, któremu zgodnie z zaleceniem Augusta towarzyszył kult bogini Romy.

Inną cechą wspólną dla wszystkich trzech prowincji było istnienie concilium. Istnienie takiej instytucji potwierdza zachowany materiał epigraficzny ${ }^{8}$. Była to rada prowincji złożona z najwyższych rangą urzędników szczebla municypalnego i prowincjonalnego, której zadaniem było między innymi wybieranie flamena, będącego jej przewodniczącym. Reprezentował on radę przed cesarzem, wstawiając się na ich wniosek u władcy w celu wyjednania łask potrzebnych dla prowincji. Najczęściej przedmiotem interwencji u władcy była nieuczciwa działalność namiestnika nastawiona na wyzyskiwanie mieszkańców prowincji. Być może spotkanie Hadriana z concilium zostało opisane we wspomnianym wyżej fragmencie dzieła Scriptores Historiae Augustae (H.A. Hadr. 12.4). Można również przypuścić, że

8 CIL II 4255 (Tarraco), CIL II 5264 (Luzytania), CIL II 2344 (Betyka). 
to właśnie concilium Tarraco zdecydowało o wysłaniu poselstwa do cesarza Tyberiusza w roku 15 n.e. Nie ma jednak żadnego źródła potwierdzającego, iż taka struktura istniała już wówczas (Fiske, 1900: 131-132)9.

Powyższy zarys etapów rozwoju kultu cesarskiego na Półwyspie Iberyjskim pozwala zauważyć, że już w początkowym etapie rozwoju inicjatywy związane $z$ oddawaniem czci cesarzowi nierzadko miały oddolny charakter. Koronnym tego przykładem jest wspomniane wyżej poselstwo mieszkańców Tarraco skierowane do cesarza z prośbą o zgodę na budowę świątyni w roku 15. Warto również zwrócić uwagę na wspomnianą już monetę z legendą Deo Augusto na awersie (RPC 221). Sam awers przedstawia Augusta siedzącego na tronie, trzymającego w prawej dłoni figurę stojącej na globie Wiktorii, a w lewej długie berło. Powszechnie przyjmuje się, że w starożytnym Rzymie żaden człowiek nie mógł być określany terminem deus. Był on zarezerwowany wyłącznie dla bóstw z Panteonu ${ }^{10}$. Użycie go w stosunku do człowieka byłoby traktowane jako pewnego rodzaju świętokradztwo. W przypadku emitentów z Tarraco mógł to więc być efekt pomyłki. Być może w dość krótkim okresie po deifikacji Augusta jeszcze nie wszyscy mieszkańcy imperium byli świadomi, jak powinna brzmieć tytulatura ubóstwionego cesarza. Fishwick sugeruje, że w tym okresie nie istniała jeszcze unormowana tytulatura określająca świeżo deifikowanego Augusta (Fishwick, 1987: 152). Takiej interpretacji wydaje się przeczyć fakt, iż w podobnym okresie emitowano monety z legendą Divus Augustus Pater wybijane w tej samej mennicy i zawierające taki sam wizerunek rewersu (RPC 219). Nieco bardziej realne wydaje się, że emitenci użyli tej formy celowo. Ich zamiarem mogło być pochlebstwo

9 Oxford Classical Dictionary 1970: 276-277: concilium.

10 Najczęściej komentowanym źródłem pisanym w którym termin deus został użyty w kontekście człowieka jest satyra pt. Udynienie boskiego Klaudiusza autorstwa Seneki Młodszego (Sen. Apocol. VIII). Podmiot liryczny wspomina w niej o tym, że Klaudiusz jest czczony w Brytanii jak deus. Badacze są jednak na ogół zgodni co do tego, że jest to tylko wyolbrzymienie na potrzeby satyry. Zob. Fishwick, 1991: 137-141. 
względem osoby cesarza Tyberiusza, mające na celu pozyskanie jego przychylności ${ }^{11}$. Humphrey Sutherland (1934: 32) uważa, że użycie formy Deo w legendzie monety było wyrazem szczerej wdzięczności wobec władcy. Również Étienne (1958: 447-448) był zdania, że Tarrakończycy kierowali się tutaj swoim pozytywnym nastawieniem wobec deifikowanego cesarza. Zastanawiający jest również przypadek, w jakim zapisana została legenda awersu - jest to dativus liczby pojedynczej. Taki przypadek sugeruje, że coś ma należeć do ubóstwionego Augusta. Może wskazywać, że coś jest mu ofiarowane bądź dedykowane. Taka forma jest bardziej charakterystyczna dla inskrypcji dedykacyjnych. W tym przypadku może odnosić się do monety, której emisja jest dedykowana boskiemu Augustowi (Divus Augustus). Istnieje również przypuszczenie, iż może to być dedykacja świątyni, której wizerunek umieszczono na rewersie. Warto w tym miejscu również zwrócić uwagę na rewers monety. Zawiera on legendę Aeternitas Augustae, opisującą cnotę integralnie związaną z boskim Augustem, być może to właśnie jej była dedykowana przedstawiona na wyobrażeniu świątynia (Fishwick, 1987: 151).

\section{4.}

\section{Inskrypcje o charakterze dedykacyjnym}

Innym przejawem oddolnego charakteru praktyk kultowych sprawowanych we wszystkich trzech prowincjach Półwyspu jest dość pokaźna liczba inskrypcji o charakterze dedykacyjnym. Ich szczególna obfitość przypada na okres od panowania Augusta do końca panowania Klaudiusza. Później powstało ich znacznie mniej. Są one jednak spotykane do końca III wieku n.e.

11 Podobny wydźwięk mogła mieć inskrypcja zawierająca dedykację dla cesarza Aureliana wystawiona w formie inskrypcji w Tarraco. Zachowana treść brzmi Deo Aureliano, zob. CIL II 3832. Niestety lakoniczność tej inskrypcji nie pozwala nam określić okoliczności jej powstania. 
Analiza inskrypcji datowanych na okres panowania Augusta ukazuje przykłady dedykacji dla samego cesarza. Co ciekawe, jest on w nich określany jako Divi filius. Jest to nawiązanie do filiacji z boskim Juliuszem, na którą powoływał się August. Niektóre $\mathrm{z}$ tych inskrypcji można datować na podstawie wskazanych w nich urzędów na lata 9-10 n.e. Taka datacja jest dość zaskakująca, gdyż w tym okresie powoływanie się na filiację z boskim Juliuszem zeszło na dalszy plan w propagandzie Augusta ${ }^{12}$. Interesująca jest również treść inskrypcji z miasta Urgavo. August jest w niej określony tytułem Pater Patriae, co jest nietypowe ze względu na fakt, iż inskrypcja została wystawiona w roku 6 p.n.e. Być może mieszkańcy miasta przypisali Augustowi tytuł, który w przeszłości otrzymał jego ubóstwiony ojciec. W treści tej inskrypcji August został również określony jako divi filius (CIL II 2107). Zachował się również przykład dedykacji dla geniusza Augusta (CIL II 3524).

Wystawcy inskrypcji dedykacyjnych z okresu panowania pierwszego princepsa objęli swoim zainteresowaniem również członków jego rodziny desygnowanych przez cesarza na jego następców. Pojawiły się inskrypcje dedykacyjne dla Tyberiusza (CIL II 5930, CIL II 6080). Uhonorowano również Lucjusza i Gajusza Cezarów - wnuków Augusta, oraz Germanika (CIL II 3104). W inskrypcjach dedykowanych wnukom wymieniono sprawowane przez nich funkcje - Princeps Iuventutis, Augur i consul designatus w przypadku Lucjusza (CIL II 2109) oraz pontifex i augur w przypadku Gajusza (CIL II 2422, CIL II 1526) ${ }^{13}$.

$\mathrm{W}$ okresie panowania Tyberiusza znajdujemy inskrypcje z dedykacjami dla cesarza, wśród nich również dedykację dla jego numen (CIL II 1516, CIL II 2181). Nie są one jednak zbyt liczne. Bardziej interesujące są powstałe w tym okresie inskrypcje $z$ dedykacjami dla członków rodziny cesarskiej. Znajdujemy dedykacje dla Liwii (CIL II 2038, CIL II 2108), Germanika (CIL II 1517, CIL II 2039, CIL II 21098) oraz dla Druzusa Młodszego (CIL II 2040,

12 CIL II 6240, CIL II 5182 (10 n.e.), CIL II 2703 (9-10 n.e.), por. Milczanowski, 2013: 214-216.

13 Być może również CIL II 2110. 
CIL II 3103, CIL II 3829). W tym przypadku również wymieniono funkcje sprawowane przez obdarowane osoby. Szczególnie warto zwrócić uwagę na to, że w inskrypcjach dedykowanych Germanikowi został podkreślony fakt objęcia przez niego funkcji flamen Divi Augusti. W przypadku Liwii podkreślano, że jest matką cesarza. Również inskrypcje dedykowane Druzusowi Młodszemu wyraźnie wskazują, że dotyczą wnuka boskiego Augusta. Zachowała się również inskrypcja dedykowana flamenowi Julii Augusty i Germanika, odnaleziona w mieście Olisippo w Luzy tanii (CIL II 194). Istnienie flamena zajmującego się kultem członków rodziny wydaje się nowością na Półwyspie. Być może był to efekt podążania za nowym trendem $w$ rozwoju kultu cesarskiego polegającym na skierowaniu zainteresowania również na członków rodziny cesarskiej tworzących domus augusta ${ }^{14}$. Należy jednak przede wszystkim zauważyć, że Olisippo było miastem o małym znaczeniu w obrębie prowincji. Wydaje się mało realne, aby powołanie opisanego w inskrypcji flamena było decyzją władz prowincji wpisującą się w imperialną politykę. Bardziej prawdopodobne jest to, iż była to decyzja dekurionów miasta Olisippo, mająca na celu schlebienie rodzinie cesarskiej.

W okresie panowania Kaliguli pojawiły się inskrypcje dedykowane jego matce - Agryppinie Starszej (CIL II 3379), a w okresie panowania Nerona w taki sam sposób uhonorowano Agryppinę Młodszą (CIL II 963). Również w późniejszych okresach pojawiały się dedykacje dla członków rodziny panującej - na przykład dedykacja dla Faustyny, żony cesarza Antoninusa Piusa (CIL II 4097). Pośród zachowanego materiału znajdują się również przykłady dedykacji, które trudno przypisać do konkretnych osób, pozostają jednak związane z kultem cesarskim. Są to dedykacje dla cnót imperialnych na przykład Veneris Augusti (CIL II 6078) oraz kolektywne dedykacje, na przykład Numini Divorum Augustorum (CIL II 2009).

14 Podobną sugestię wysunął Sutherland (1934: 34). Na temat Domus Augusta zob. Sajkowski, 2004: 373-374. 


\section{5.}

\section{Emisje monetarne związane z kultem cesarskim}

Inskrypcje dedykacyjne $\mathrm{z}$ natury miały charakter prywatny i spontaniczny. $Z$ tego powodu można je uznać za przejaw inicjatywy oddolnej. Chociaż istnieje jednak prawdopodobieństwo, że ich fundatorzy, nierzadko sprawujący publiczne funkcje, byli inspirowani przez Rzym, bardziej realne wydaje się jednak, że ich dedykacje były spontaniczną reakcją. Warto zwrócić uwagę na fakt, iż w tym samym czasie w Hiszpanii emitowano monety honorujące członków rodziny cesarskiej. Za panowania Augusta wybito monety z wizerunkiem Gajusza i Lucjusza Cezarów (RPC 202, 207). Szczególnie warte uwagi są emisje zawierające na awersie przedstawienie Augusta, $\mathrm{z}$ rewersem przedstawiającym głowy obu braci skierowane do siebie twarzami. Legenda rewersu wymienia ich imiona oraz wskazuje na filiację z Augustem (RPC 210). Wcześniej pojawiły się emisje wskazujące na pochodzenie Augusta od boskiego Juliusza (legenda: IMP CAESARI DIVI F AUGUSTO).

W okresie panowania Tyberiusza pojawiły się monety przedstawiające Liwię (RPC 38, 39), Germanika (RPC 75, RPC 232) i Druzusa Młodszego (RPC 68). Liwię przedstawiano również na wspólnych emisjach z boskim Augustem (RPC 66,73) i Tyberiuszem (RPC 40), a nawet Druzusem Młodszym (RPC 233). Germanik i Druzus zostali przedstawieni na jednej z tarrakońskich emisji podobnie do Gajusza i Lucjusza. Awers monety przedstawia głowę Tyberiusza, jego legenda wskazuje na filiację Tyberiusza z boskim Augustem (TI CAESAR AUGUSTI F). Rewers monety przedstawia następców Tyberiusza, którzy są zwróceni do siebie twarzami. Legenda rewersu podaje ich imiona (RPC 232).

Emisje monetarne pochodzące z mennic w Tarraco i Augusta Emerita miały charakter lokalny. Były emitowane przez miejscowych nobilów, a ich zasięg obejmował przede wszystkim Półwysep Iberyjski. Ich treść wyraźnie naśladuje legendy i wyobrażenia obecne na monetach emitowanych w mennicach imperialnych. W efekcie były nośnikiem propagandy imperialnej, 
zwłaszcza propagandy rodowej cesarzy. Popularność lokalnych emisji na Półwyspie może potwierdzać, iż propaganda cesarska trafiła na podatny grunt. Być może to właśnie treści powielane za pomocą legend monet stanowiły inspirację dla treści inskrypcji dedykacyjnych wystawianych przez mieszkańców Półwyspu. Nie ulega również wątpliwości, że pokaźna liczba emisji pochodzących z lokalnych mennic stanowi kolejny przykład oddolnej inicjatywy mieszkańców Półwyspu w zakresie rozpowszechniania kultu cesarskiego.

\section{6. \\ Postawa Hispanorzymian na tle pozostałych prowincji}

Warto również zwrócić uwagę na fakt, że postawa mieszkańców Półwyspu Iberyjskiego wobec przyjęcia kultu cesarskiego wyróżnia się na tle innych prowincji zachodniej części cesarstwa. W przypadku pozostałych prowincji - Galii, Germanii i Brytanii poświadczone przypadki wskazują, że kult cesarski był narzucany odgórnie, a wystawianie ołtarzy i świątyń niekiedy spotykało się z oporem mieszkańców. W Lugdunum powstał ołtarz dedykowany Augustowi, prawdopodobnie czczonemu wraz z boginią Romą. Jego budowa i dedykacja była ściśle nadzorowana przez Druzusa. Dedykował go Gajusz Juliusz Vercundaris Dubius, kapłan pochodzący z sojuszniczego wobec Rzymu plemienia Eduów. Następnie sprawował funkcję kapłana przy ołtarzu (Cass. Dio LIV, 32; Liv. Epit. CXXXVII).

W podobnych okolicznościach został dedykowany ołtarz w kraju Ubiów, znajdującym się w opanowanej przez Rzymian części Germanii. Tam również wyznaczono na kapłana zaprzyjaźnionego z Rzymem nobila wywodzącego się z miejscowego plemienia Cherusków. Tym razem był to Segismundus, syn Segestesa, przywódcy plemienia. W 9 roku n.e. doszło tam do powstania, do którego przyłączył się Segismundus. Powstanie pod wodzą Arminiusza było wymierzone przeciwko Segestesowi 
i Rzymianom, a jego zarzewiem było istnienie ołtarza (Tac. Ann. I, 57-59). W Brytanii powstała świątynia dedykowana boskiemu Klaudiuszowi. Jej istnienie i być może, jak uważa Fishwick, również pieniądze zebrane od miejscowej ludności na jej budowę doprowadziły do krwawego powstania Budyki w 60 n.e. (Tac. Ann. XIV, 32-39). Postawa Iberów wydaje się bliższa mieszkańcom prowincji wschodnich, znajdujących się w obrębie greckojęzycznej części Imperium. Władze tamtejszych prowincji same wychodziły z inicjatywą uhonorowania cesarza budową świątyni lub organizacją igrzysk. Oprócz wspomnianych wyżej poselstw z Pergamonu i Nikomedii oraz poselstwa wysłanego do Tyberiusza przez mieszkańców Azji warto również wspomnieć o propozycji uhonorowania Tyberiusza wraz z Liwią, Germanikiem i Druzusem Młodszym, jaką wysunęli mieszkańcy miasta Gytheion w Lakonii. W przysłanym do cesarza liście zaproponowali oni organizację sześciodniowych igrzysk na cześć rodziny cesarskiej. Podczas kolejnych dni igrzysk mieli zostać uczczeni boski August, Tyberiusz, Liwia, Germanik, Druzus Młodszy oraz Tytus Kwinktus Flamininus, zapamiętany w Grecji, jako ten który ogłosił wolność greckich poleis (EJ 102).

\section{7. \\ Podsumowanie}

Powyższa analiza potwierdza, że inicjatywy podejmowane przez mieszkańców Półwyspu Iberyjskiego w zakresie kultu cesarskiego miały charakter oddolny. Dowodzi tego fakt, że to mieszkańcy Tarraco jako pierwsi wysłali poselstwo z propozycją wystawienia świątyni dla boskiego Augusta. Wkrótce potem poszli za nimi mieszkańcy kolejnych prowincji. Potwierdza to również dość pokaźna liczba inskrypcji o charakterze dedykacyjnym datowanych na okres panowania dynastii julijsko-klaudyjskiej. Co więcej, afirmatywna postawa Hispanorzymian wobec kultu cesarskiego wyróżniała ich na tle pozostałych prowincji zachodniej części Imperium. 
Na koniec warto poszukać odpowiedzi na pytanie, co mogło być przyczyną takiego stanu rzeczy. Nasuwają się trzy możliwe wyjaśnienia takiej postawy. Po pierwsze, mogła ona zostać narzucona lub przynajmniej zainspirowana przez Rzym. Tak było w przypadku sąsiednich prowincji, położonych na zachodzie cesarstwa. Trudno jednak odnaleźć jednoznaczny przykład narzucenia Hispanorzymianom określonych praktyk kultowych przez Rzym. Być może jedynie treść inskrypcji dedykacyjnych i legend monet emitowanych na Półwyspie była inspirowana mennictwem imperialnym. Może na to wskazywać podobieństwo prezentowanych przez nie treści.

Bardziej prawdopodobne wydaje się jednak, iż postawa Hispanorzymian miała na celu zdobycie zaufania i przychylności cesarza. Mieszkańcy Półwyspu mogli dążyć do uzyskania pewnego rodzaju opieki ze strony władcy. Przemawia za tym wykształcenie się concilium we wszystkich trzech prowincjach potwierdzone przez źródła epigraficzne. Jednym z zadań tej rady było interweniowanie u cesarza w celu uzyskania ochrony przed namiestnikiem wyzyskującym daną prowincję.

Istnieje również prawdopodobieństwo, że mieszkańcy Półwyspu chcieli wyjednać sobie łaskę cesarza, aby odzyskać utracone zaufanie. Warto zwrócić uwagę na fakt, że tamtejsza ludność w okresie wojen domowych popierała Pompejuszy - najpierw Gnejusza Pompejusza Wielkiego, a potem jego synów - Gnejusza i Sekstusa Pompejuszów. Być może przynajmniej w okresie panowania Augusta i Tyberiusza mieszkańcy tej prowincji zabiegali o odzyskanie utraconego zaufania.

\section{Bibliografia}

\section{Wykaz skrótów}

AE = L’Année épigraphique, Paris 1889-

Caes. Bciv. $=$ Caius Julius Caesar: Commentatorium: Libri III de Bello Civili cum Libris Incertorum Auctorum de Bello Alexandrino Africo Hispaniensi. R. du Pontet (eds.). Oxford: Univesity Press 1901. 
Cass. Dio. = Cassius Dio: Roman History. E. Cary (eds.). Harvard: University Press 1914-1927.

CIL $=$ Corpus Inscriptionum Latinarum. Berlin: 1863-

EJ = Documents Illustrating the Reigns of Augustus and Tiberius .

V. Ehrenberg (eds.). Oxford: University Press 1949.

H.A. = Scriptores Historiae Augustae Vol I. D. Magie (eds.). Harvard Univeristy Press 1921.

Liv. Epit. = Titus Livius: Ab urbe condita Vol. IV Libri XLI-CXLII Fragmenta. M. Mueller (eds.). Leipzig 1911.

Plin. HN = Plinius Maior, Naturalis Historia. K. Mayhoff (eds.). Leipzig: Teubner 1906.

Quint. Inst. = Institutio Oratoria [w:] Quintilian, With An English Translation. H.E. Butler (eds.). London: Heideman 1921.

$\mathbf{R P C}=$ Roman Provincial Coinage: Vol. I from the death of Caesar to the death of Vitellius. P. Pau Ripollès (eds.). London British Museum Press, 1992.

Sen. Apocol. = Seneca: Apocolocyntosis. W. Rouse (eds.). London: Heideman 1913.

Suet. Aug. = Caius Suetonius Tranquillus: De Vita Cesarum Libri XIII [w:] Id., Opera Vol. I. M. Ihm (eds.), Leipzig: Teubner 1933.

Tac. Ann. = Cornelius Tacitus: Annales ab excessu Divi Augusti.

C. Fisher (eds.). Oxford: University Press 1906.

\section{Literatura przedmiotu}

Alföldy, G. (1975): Die Römischen Inschriften Von Tarraco. Berlin: W. de Greuter.

Beard, M., North, J., Price, S. (2017): Religie Rzymu, Historia. Oświęcim: Napoleon V.

Bickermann, E. (1973): Consecratio, w: Le Culte Des Souverains Dans L’Empire Romain, ed. W. den Boer. Vandœuvres-Geneva: Fondation-Hardt: 1-37.

Étienne, R. (1958): Le culte imperial dans la péninsule ibérique d'Auguste a Dioclétien. Paris: E. De Boccard.

Fishwick, D. (1970): Flamen Augustorum. „Harvard Studies in Classical Philology" 74: 299-312. 
Fishwick, D. (1972): Templum Divo Claudio Constitutum. „Britannia" 3: 164-181.

Fishwick, D. (1978): The Development of Provincial Ruler Worship in the Western Roman Empire. „Austieg und Niedergang der Römischen Welt" II 2.16.2: 1201-1254.

Fishwick, D. (1982): An Early Provincial Priest of Lusitania. „Historia: Zeitschrift für Alte Geschichte” 31, Fasc. 2: 249-252.

Fishwick, D. (1987): The Imperial Cult in Latin West Vol. 1. Leiden: Brill.

Fishwick, D. (1991): Seneca and The Temple of Divus Claudius. „Britannia” 22: 137-141.

Fishwick, D. (1996): Four Temples at Tarraco, [w:] Subject and Ruler: The Cult of the Ruling Power in Classical Antiquity, ed. A. Small, Ann Arborn: University Press: 165-184.

Fishwick, D. (1999a): The «Temple of Augustus» at Tarraco. „Latomus" 58, Fasc. 1: 121-138.

Fishwick, D. (1999b): A Municipal Decree at Tarraco. „Zeitschrift für Papyrologie und Epigraphik" 126: 291-295.

Fishwick, D. (2004): The Imperial Cult in Latin West Vol. 3. Boston-Leiden: Brill.

Fishwick, D. (2014): The Status and Location of the Altar of Augustus at Tarraco. „Phoenix”: 68, nr 3-4:350-358.

Fiske, G.C. (1900): Notes on the Worship of the Roman Emperors in Spain. „Harvard Studies in Classical Philology” 11: 101-139.

Herz, P. (1988): Der römischer Kaiser und der Kaiserkult, Gott oder primus inter pares?, w: D. Zeller (red.), Menschwerdung Gottes - Vergöttlichung von Menschen. Göttingen: Vandenhoen \& Ruprecht: 1988: 115-140.

Keay, S. (2003): Recent Archaeological Work in Roman Iberia (1990-2002). ,The Journal of Roman Studies” 93: 146-211.

Kopaliński, W. (1990): Słownik symboli. Warszawa: Wiedza Powszechna.

Machcewicz, P., Miłkowski, T. (2009): Historia Hiszpanii. Wrocław: Ossolineum.

Milczanowski, M. (2013): W cieniu boskiego Juliusza, imię Cezara w propagandzie schyłku republiki. Kraków: Historia Jagiellonica. 
Olszewski, L. (2010): „Religia” $i$ „kult cesarski” w Starożytnym Rzymie - $z \dot{z} y c i a$ pojęć, w: S. Olszaniec, P. Wojciechowski (red.), Społeczeństwo i religia wświecie antycznym. Toruń: Uniwersytet: 361-377.

Oxford Classical Dictionary (1970): Hammond N., Scullard H. (eds.). Oxford: University.

Sajkowski, R. (2004): Domus Augusta - domus divina, w: L. Morawiecki, et. al (red.), Ideologia i propaganda w starożytności, Materiały konferencji Komisji Historii Starożytnej PTH. Rzeszów 12-14 września 2000. Rzeszów: Fraza: 369-382.

Price S.R.F. (1984): Rituals and Power: The Roman Imperial Cult in Asia Minor, Cambridge: University Press.

Sutherland, C.H.V. (1934): Aspects of Imperialism in Roman Spain . „The Journal of Roman Studies” 24: 31-42. 